\title{
URALS FACTORY HOSPITALS AND SURGEONS AT THE DAWN OF THE NINETEENTH CENTURY
}

by

\author{
BASIL HAIGH*
}

\section{INTRODUCTION: THE INDUSTRY AND ITS PROBLEMS}

AT THE BEGINNING of the nineteenth century 128 mines and metallurgical factories were in operation in the Ural Mountains. Many had been destroyed in Pugachev's rebellion (1773) but they had been quickly rebuilt. As a result of periodic changes in government policy in the previous century, when private enterprise was alternately encouraged and discouraged, twenty-four of the factories ${ }^{1}$ belonged to the Crown and the rest (the ownership of one is not clear) were privately owned. The 128 factories were spread over a territory about equal in area to the entire United Kingdom. They depended for their communications on rivers which were frozen for half the year and on post roads which were frequently impassable.

The metallurgical industry was semi-military in character and was administered on military lines. Recruiting the labour force in the sparsely populated and remote region of the Urals was always a difficult problem and various solutions were tried. The Ukase of 18 January $1721^{2}$ empowered the nobility and merchants to purchase villages to obtain serf labour for factory work, with safeguards to ensure that peasants thus obtained were in fact used for that purpose. Otherwise convicts were employed, supplemented by a steady influx of children and by a leavening of skilled workers and "masters", who were often foreigners or foreign-trained. This system, inefficient and wasteful of manpower, made it necessary to have an enormous population of permanent and seasonal workers, with their families, at the factories and, consequently, it increased the need for some form of health service. ${ }^{3}$ The factory population was further increased by the military garrison needed both to maintain internal order and to protect the factory and its inhabitants against external attack by hostile neighbours.

The naturalist P. S. Pallas (who was also medically qualified) visited nearly a hundred factories in the whole of Siberia in 1768-1774 and described some of the medical problems. At some of the more remote factories scurvy was rife. At Petro*Basil Haigh, M.A., M.D., F.I.L., 28 Roman Hill, Barton, Cambridge CB3 7AX. This paper is based on material collected for an unpublished thesis (M.D., University of Cambridge) entitled "The early development of industrial medicine in Russia", submitted on 18 April 1974.

1 For brevity, the mines, furnaces, forges, mints, etc., are collectively described as factories.

2 Polnoe sobranie zakonov rossiiskoi imperii [Complete collection of laws of the Russian Empire], first series (to 1825), VI, No. 3711, St. Petersburg, 1830 (title hereinafter abbreviated to PSZ-1).

- At the 1794-1796 census there were 312,218 ascribed peasants at the Urals factories, the majority at factories owned by the Crown. See V. I. Semevskii, Krest'yane $v$ tsarstvovanie Imperatritsy Ekateriny II [The peasants during the reign of Empress Catherine II], St. Petersburg, 1903, pp.304-305.

'P. S. Pallas, Voyages de M. P. S. Pallas, en différentes provinces de l'Empire de Russie, et dans l'Asie septentrionale, translated from German by Gauthier de la Peyronie, Paris, Lagrange, 1788, vol. II, pp. 173-438. 


\section{Basil Haigh}

pavlovskoi, for example, he states: "Four thousand peasants are employed for wood cutting, charcoal burning, carting ore, etc.; they have been ascribed to these factories for a certain number of years to pay off their poll tax. They are from the district of Cherdyn', a town on the other side of the mountains, looking to Solikamsk. Most of these peasants are forced to travel here on foot, over these boggy mountains, and they groan under oppression. The hardest thing of all for them is that, when they have worked their allotted time, those who have not died from scurvy return home sick."

Other major diseases were smallpox and anthrax. Venereal diseases were less of a problem than in the towns, but alcoholism was a serious social evil. Pallas also describes the working conditions vividly and mentions poor ventilation and water as hazards of underground working and the frequency of explosions in the forges: "For some deplorable reason the dangerous use of cast iron hammers has been introduced both here (Verkhne Tagil'skoi) and at Nev'yanskoi . . .; sometimes they burst at the first blow, or during the first day, or at least after a few days of service, so that the lives of the workers are always at risk."

To fill in the details of the pattern of life and work at the factories some objective statistics are available, not for the Urals, but for the Altai district of Western Siberia, where the conditions were similar. ${ }^{5}$

At the Salairskie mines in 1795 there were 844 workers aged between seven and seventy years. Boys and adolescents aged from seven to fifteen years accounted for nine per cent of the total. Youths aged from sixteen to twenty-four years were the most numerous group (41 per cent). Fewer than 2 per cent of the workers were over fifty-five years old, and one-third of them were "invalids" employed on light work. Among the group from forty-five to fifty-four years old there were about 25 per cent of working "invalids". The very small number of workers over fifty-five years of age and the high percentage of invalids in the older age groups reflect the high incidence of trauma and the arduous working conditions. Of the seventy-nine boys and adolescents aged seven to fifteen years, seventy-seven worked as ore sorters, which was the only trade available at that age. The commonest trade of the largest group, aged sixteen to twenty-four years, was "bergauer" or miner. The next age group, aged twenty-four to thirty-four years, also consisted mainly ( 66 per cent) of miners, but it also included more deputies ("untersteiger"), more charcoal-burners and more skilled fillers than any other group. The group aged thirty-five to forty-four years had a large proportion of unskilled underground and surface workers, together with both of the two blacksmiths, one of the three dam- and wheel-men, and four of the twenty-four charcoal-burners.

The factories and mines worked round the clock. Masters worked two twelve-hour shifts, while haulage (winch) and pump operators, whose jobs were particularly arduous, had shifts of eight to ten hours.

Holidays were numerous: Sundays, religious holidays, the name days of the Tsar's or Tsarina's family. Masters were given time off for Lent, for communion and for haymaking. Consequently, about one-third of all the days in the year were non-working days.

' Z. G. Karpenko, Gornaya i metallurgicheskaya promyshlennost' Zapadnoi Sibiri v 1700-1860 godakh [The mining and metallurgical industry of Western Siberia in the years 1700-1860], Novosibirsk, Izd. Sibir. Otdela Akad. Nauk SSSR, 1963, pp. 68-88. 


\section{Urals factory hospitals and surgeons}

\section{EARLY RUSSIAN INDUSTRIAL MEDICAL LEGISLATION}

Before examining the medical service as it existed in the Urals at the beginning of the nineteenth century, let us glance briefly at earlier industrial medical legislation and practice in Russia.

The first organized medical service in Russian industry was that set up by edict of Peter the Great (1682-1725), contained in the Admiralty Regulations of 1722," at the Admiralty Dockyard in St. Petersburg, where hospital facilities were provided both for sailors of the Baltic Fleet and for the local dockyard workers. The nearby ordnance factory at Sestroretsk acquired a surgeon by government decree in $1734 .^{7}$

When the town of Ekaterinburg was built on the Siberian side of the Ural Mountains in 1723 to serve as a garrison and as the administrative headquarters of the Siberian mining industry, a hospital was included among its facilities. The "Schedule of emoluments paid to Chancellery and other servants of the Oberbergamt" specifies one senior and one junior surgeon, "one to go on horseback to all factories and mines near Ekaterinburg," one senior and one junior apprentice, an overseer, a copyist, two guards, and two female workers for the hospital. The first surgeon appointed to the Ekaterinburg hospital was Johann Josif Sprinzel, who accompanied the new Director of the Siberian Oberbergamt, Wilhelm de Hennin, when taking up his post in 1723 , and remained there until $1736 .^{8}$

The naturalist and physician Johann Georg Gmelin visited Ekaterinburg in 1733 and was favourably impressed by what he found. ${ }^{\vartheta}$ He mentions the hospital only briefly: "In other matters the workers lack nothing; they are paid regularly, the cost of living is low, and they are treated in hospital when they are sick."

Both Hennin and his successor, Tatishchev, had enlightened ideas on the organization of industrial society. Hennin drew up a "Precept" [Nakaz], a document with instructions on management of the factories during his absence on tours of duty, and one of its fifteen chapters, with twenty-two articles, deals with "maintenance of the dispensary [apteka], surgeon [lekar'] and poorhouse". ${ }^{10}$ Tatishchev, who was Director of the Siberian Oberbergamt from 1734 until 1739, had remarkably progressive views on industrial administration and welfare, which were embodied in his "Factory Code"

- PSZ-1, VI, No. 3937, 5 April 1722. For an analysis of the medical aspects of the Admiralty Regulations, see B.Haigh, 'Design for a medical service', Med. Hist., 1975, 19: 129-146.

$7 P S Z-1$, VII, No. 4442, 27 January 1724.

- Georg Wilhelm Henning (de Hennin), born in 1674 in Siegen, famous for its iron manufactures, in the small German state of Nassau, joined the Russian service under Peter the Great in Amsterdam, with the rank of Artillery-Captain, and subsequently moved into the Ordnance department. He was appointed director [nachal'nik] of the Siberian Oberbergamt in March 1722 and organized the reconstruction of the factories and founded the town of Ekaterinburg. For Hennin's account of the industry, see Wilhelm Hennin, Opisanie ural'skikh $i$ sibirskikh zavodov [Description of the Urals and Siberian factories], reprinted with a preface by Academician M. A. Pavlov and an introduction by M. F. Zlotnikov [in Russian], Moscow, Istoriya Zavodov, 1937. For further details of Hennin's origins and career, see A. Lück, 'Georg Wilhelm Henning: Ein Siegener als Organisator der sibirischen Eisenindustrie zur Peters des Grossen', Siegerland, 1972, 49: Heft 1, 9-24.

- J. G. Gmelin, Voyage en Sibérie, translated into French by M. de Keralio, Paris, 1767, pp. 115118.

${ }_{10}$ Unfortunately only the titles of the chapters are given by B. J. F. von Hermann, Istoricheskoe nachertanie gornago proizvodstva $v$ rossiiskoi imperii [Historical sketch of the mining industry of the Russian Empire], Ekaterinburg, Gornaya Tipografiya, 1810, p. 47. They were no doubt inspired by the Admiralty Regulations. 


\section{Basil Haigh}

[Zavodskii Ustav]. ${ }^{11}$ Of the eight chapters of the Factory Code that are extant, one is devoted entirely to "the Doctor of Medicine or Berg-Physik" and contains nineteen articles, and four articles from other chapters deal with poorhouses, treatment of the sick, deductions from pay to meet the cost of medicines, and hours of work. Space precludes a full examination of this remarkable document, years ahead of its time, which was fortunately published for the benefit of posterity almost a century later. ${ }^{12}$ In any event, there is little evidence of its implementation.

Later in the eighteenth century surgeons were appointed to several factories and hospitals were provided to meet local needs and conditions, as is clear from a variety of documentary sources. The Konchozerskoi iron and copper foundry, belonging to the Olonets group near St. Petersburg, had an apprentice surgeon in 1744 to treat its workforce of 216 people. ${ }^{13}$ By edict of the Senate a staff surgeon and two apprentice surgeons were appointed in $\mathbf{1 7 5 8}$ to the Kolyvano-Voskresensk factories in the Altai district of Siberia. ${ }^{14}$ In 1767 a surgeon was posted from the Medical College in St. Petersburg to the Nerchinsk silver mines in Eastern Siberia to treat the factory peasants, for venereal diseases were rife among them. ${ }^{15}$ Pallas, in his descriptions of the mines and factories of the Urals, does not mention either surgeons or hospitals, but at the Zmeinogorsk, Barnaul, and Nizhne Susunskie factories in the Altai district he found hospitals and surgeons of commendable quality. ${ }^{16}$ On his visit to the same district in 1782, Samuel Bentham was entertained by "Mr. Klangen, Imperial Surgeon at the mines of Barnaul."17 Other factories for which there is documentary evidence of the presence of a surgeon include Tula, near Moscow, Serebryanskoi, Nizhne-Turinskoi, Votkinskoi, Goroblagodatskoi and Berezovskoi in the Urals, and Lugansk in the Ukraine. ${ }^{18}$ Assistant-surgeon Hofman, one of the first

11 Vasilii Nikitich Tatishchev (1686-1750), born in Pskov, the son of a provincial governor, served with distinction in the Azov Dragoons at Narva (1704) and Poltava (1709), and then at the Artillery School founded by Yakov Vilimovich Bruce, the son of a Scottish major-general in the Russian army who was the first President of the Mining College (Berg-Kollegiya). After a tour of Germany to study mining and metallurgy, during which he collected a large library, Tatishchev was sent by Peter the Great to take charge of the Urals mining industry in 1720. Following a dispute with Nikita Demidov, the leading mine-owner, he was recalled, but was again posted to the Urals on Hennin's retirement from the directorship in 1734. See V. Rozhkov, 'Deyatel'nost' artilleri-kapitana V. N. Tatishcheva na ural'skikh zavodakh $\mathrm{v}$ tsarstvovanie Petra Velikago' [Activities of Artillery-Captain V. N. Tatishchev at the Urals factories in the reign of Peter the Great], Gornyi Zhurnal, 1884, Book III, No. 7 pp. 94-128; No. 8, pp. 246-282.

12 Full details of Tatishchev's Factory Code are given in: 'Zavodskii ustav Tatishcheva' [Tatishchev's factory code], ibid., 1831, Book I, No. 1, pp. 1-5; Book II, pp. 172-192; Book VI, pp. 342-344; Book IX, pp. 320-328.

${ }^{13}$ From a list in the archives of the Berg Kollegiya cited by N. I. Pavlenko, Istoriya metallurgii v Rossii XVIII veka [The history of metallurgy in 18th century Russia], Moscow, Izd. Akad. Nauk SSSR, 1962, p. 242.

14 PSZ-1, XV, No. 10,823, 10 April 1758. 1s PSZ-1, XVIII, No. 12,893, 10 May 1767.

16 Pallas, op. cit., note 4 above, vol. III, pp. 337-342.

${ }^{17}$ In a letter to his brother Jeremy, Samuel proposes sending Klangen a microscope. See I. R. Christie (editor), Correspondence of Jeremy Bentham, vol. 3 (1781-1788), pp. 171-174, in the series: J. H. Burns (general editor), Collected works of Jeremy Bentham, London, University of London Athlone Press, 1971.

${ }^{18}$ Material in the Central State Historical Archives, Leningrad, cited by R. Yu. Matskina, Istoriya razvitiya meditsiny $i$ zdravookhraneniya $v$ Rossii [History of the development of medicine and health care in Russia]. A survey of documentary materials, edited by B. D. Petrov, Moscow and Leningrad, Glavnoe Arkhivnoe Upravlenie, 1958, p. 34. 


\section{Urals factory hospitals and surgeons}

two apprentice surgeons to be trained at the new hospital in Ekaterinburg, was posted to the Alapaev factories, according to the records of the Medical Chancellery, because "the number of these factories has increased and it is difficult to transport the sick to hospital in Ekaterinburg 70 versts [45 miles] away."19

\section{THE NINETEENTH CENTURY}

In the early years of Alexander I's reign (1801-1825) the mood was one of liberalism and reform, and this was reflected in the legislation on health and welfare of the industrial worker.

When there was a change of ownership of a factory, of a kind requiring governmental sanction, the opportunity was taken to stipulate the welfare services required by law. For instance, when the Kupava silk mill was transferred from Crown ownership to the hereditary estate of Prince Yusupov"20 it was decreed that "the factory owner must provide a decently equipped poorhouse for those workers who, because of old age, sickness or infancy, are unable to do factory work. ... The owner must take the necessary care of all who should fall ill at the factory, with regard both to their upkeep and to their treatment."

Legislation for the Imperial Porcelain Factory ${ }^{21}$ and the Imperial Glass Factory ${ }^{22}$ specifically mentioned that a hospital and surgeon must be provided. In 1804, surgeons were appointed to the Goroblagodatsk and Perm Mining Administrative Departments and their stipends fixed. ${ }^{23}$ In the same year funds were assigned for maintenance of the sick in hospital at the Perm Crown Salt Factory, ${ }^{24}$ and for the provision of a surgeon and hospital at the Ekaterinburg Cutting and Polishing Factory, ${ }^{25}$ the Irkutsk Cloth Factory, ${ }^{26}$ and the Pavlovsk Crown Factory. ${ }^{27}$

However, the major landmark in Russian industrial medical legislation is the "Mining Regulations" [Gornoe Polozhenie] approved in draft form by Tsar Alexander I in 1806 for a trial period of five years, which was subsequently extended. ${ }^{28}$

The Regulations were submitted for the Tsar's approval by the Minister of Finances, Count Vasil'ev, who explained in his speech reported in the preamble why they were necessary. On the matter of medical services the Count had this to say: ${ }^{29}$

Formerly hospitals were established only at some of the principal factories. The sick, whatever the nature of their illness and however bad the weather, in the most oppressive heat or the severest frost, were transported from other factories to these hospitals, dozens of versts or more away. Often the journey itself was the cause of their death. Now, however, it is ruled that a hospital

10 Material in the Central State Historical Archives, Leningrad, cited by I. P. Mokerov, 'Istoriya meditsinskogo obsluzhivaniya rabochim promyshlennykh predpriyatii Urala' [History of medical care of industrial workers at Urals factories], Sovetskoe Zdravookhranenie, 1961, 20: No. 12, 70-74.

${ }^{20}$ PSZ-1, XXVII, No. 21,074, 11 December 1803.

${ }^{21}$ PSZ-1, XXVIII, No. 21,152, 13 February 1804.

22 PSZ-1, XXVIII, No. 21,153, 13 February 1804.

23 PSZ-1, XXVIII, No. 21,339, 8 June 1804.

24 PSZ-1, XXVIII, No. 21,365, 24 June 1804.

${ }^{25}$ PSZ-1, XXVIII, No. 21,483, 21 October 1804, Kniga shtatov [Book of statutes], p. 47.

26 PSZ-1, XXVIII, No. 21,563, 20 December 1804, Kniga shtatov [Book of statutes], p. 49.

${ }^{27}$ PSZ-1, XXVIII, No. 21,583, 31 December 1804.

28 PSZ-1, XXIX, No. 22,208, 13 July 1806. This all-embracing statute contains some 100,000 words. A noteworthy feature is a dual system of inspection and enforcement of the law, by the factory police and the mines inspectorate.

${ }^{20}$ Ibid., p. 463, paragraph 14. 


\section{Basil Haigh}

shall be established at every factory. Rules are laid down in the Polozhenie on how and on what basis they shall be maintained at Crown factories and also at factories belonging to private persons.

These rules concerning the maintenance of hospitals and the decrees relating to medical officers and to their organization, chain of command, privileges, rights, etc., are taken from the "Regulations for Medical Administration of the Army and Navy", which received Your Royal Highness' Royal assent on 4 August 1805.20 These regulations have been adapted to the circumstances and to the essential character of affairs of this Department at metallurgical factories .... Further, unless essential parity is created between medical officers serving in different Departments it will be impossible to recruit them for the factories; for the remoteness of these places from towns, the lack of many of the pleasures of life for those who live there, the absence of society or its limitation, and other like reasons create greater difficulties in the way of recruiting medical officers for these posts than for any others.

Factory owners are also obliged by these Regulations to maintain hospitals and surgeons at their factories. This obligation, so necessary on humanitarian grounds, cannot be interpreted as a hardship by the owners. The good of the people and the good of mankind, for which Your Imperial Highness consents every day to give innumerable expressions of Your fatherly care, and for the furtherance of which the Government, in all its Departments, is taking the most active measures, will of course compel the factory owners to fulfil their obligations willingly, not least because it requires no great sacrifice.

Turning to the Polozhenie itself, it is interesting to note that of the over 800 articles which it contains ten deal with ill-health or disablement pensions, twenty-eight (the whole of Chapter XI) with poorhouses for old and disabled employees, and forty-three (the whole of Chapter XII) with hospitals and medical officers at mines and factories.

This remarkable and comprehensive Act covered all aspects of the metallurgical industry. The provisions relevant to our theme at present are the following: every factory employing more than 200 persons must have a hospital to which any employee, whatever his state or rank, is entitled to be admitted for treatment without charge for medicines (Articles 678, 681, 682 and 683); each factory hospital must be staffed by a surgeon (Article 680); at the discretion of the Inspector of Mines [Berg-Inspektor] or Manager [Gornyi Nachal'nik] a physician may also be appointed to a larger hospital (Article 678); a poorhouse must be built at every factory, or one can serve two factories if close together, and all poor, destitute, and disabled persons belonging to the factory shall have the right to be accommodated there (Articles 650 and 651).

\section{STATE OF THE FACTORIES IN 1807}

After this introductory survey of the industry, its hazards, and measures taken or proposed for their amelioration, the time has come to tackle the main problem and to describe the industrial medical scene in the Urals as it was immediately after the enactment of the Gornoe Polozhenie. Two recently republished documents enable this to be done adequately, if not completely.

The first essential is an inventory of all the factories. When the industry had recovered from the damage caused by Pugachev's rebellion, the headquarters of the mining industry was re-established in Ekaterinburg and one of its first orders was to request reports from the Provincial departments on the state of the factories under

${ }^{20}$ PSZ-1, XXIX, No. 21.866, 4 August 1805, and Kniga shtatov [Book of statutes]. 


\section{Urals factory hospitals and surgeons}

their jurisdiction. These reports were collected to form a "General description of the Mines, Foundries and all Metallurgical Factories administered by the Mining College", which was published in 1797.31 A complete list of the Urals factories with their owners, taken from this description, is given in Table 1 . The factories are numbered and a reference given to their location on Map 1 (p. 128).

TABLE 1

Mines and Factories in the Urals in 1807: Location, Ownership, Population and Facilities

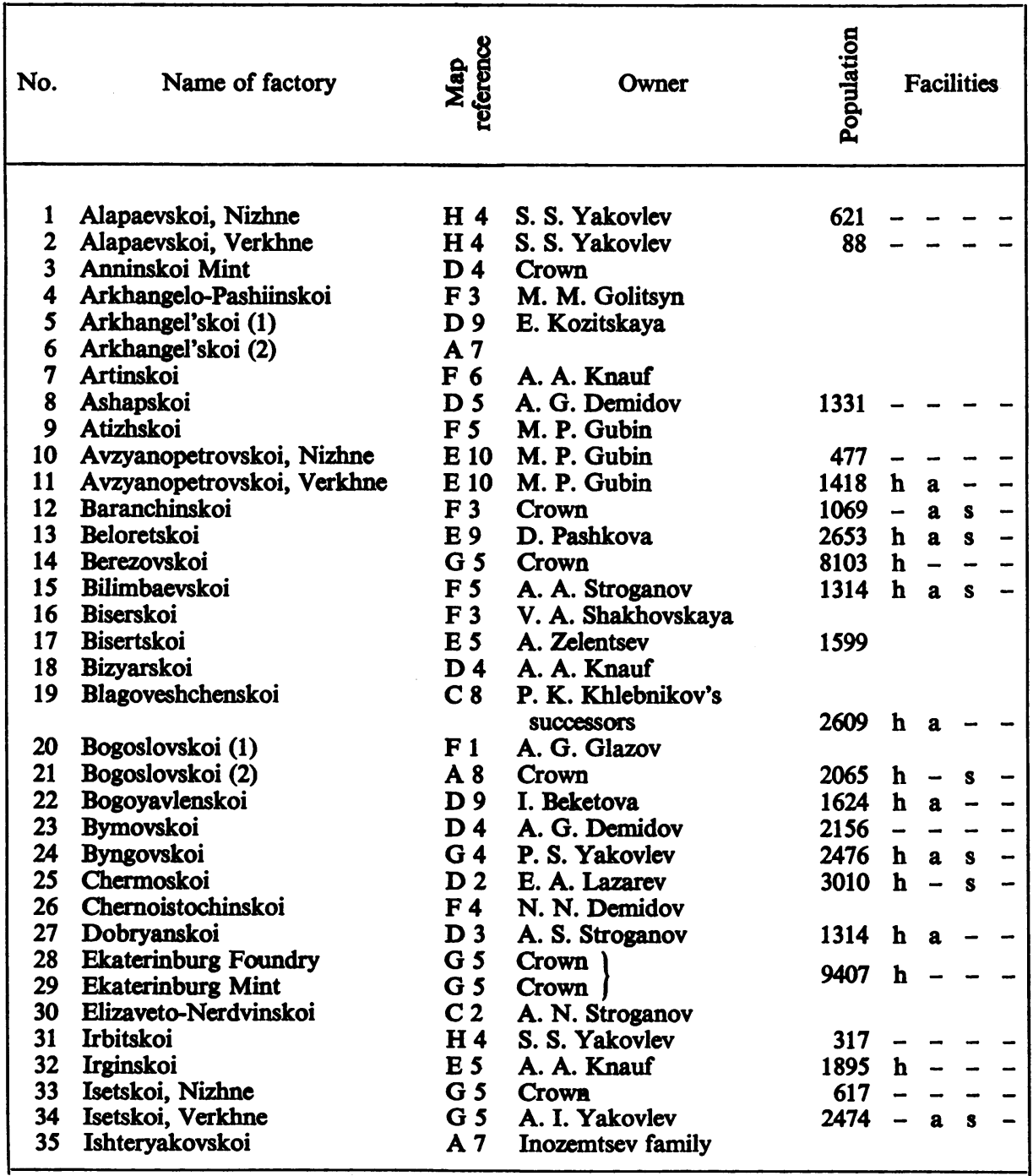

81 The original title is "General'noe opisanie o monetnykh dvorakh, liteinykh $i$ usekh gornykh zavodakh, v vedenii Gosudarstvennoi Berg-Kollegii sostoyashchikh." It is reprinted in A. G. Kozlov (editor-in-chief), Gornozavodskaya promyshlennost' Urala na rubezhe XVIII-XIX vv. [The Urals mining industry in the late 18th and early 19th centuries], Sverdlovsk, Ural. Filial Akad. Nauk SSSR, 1956. 


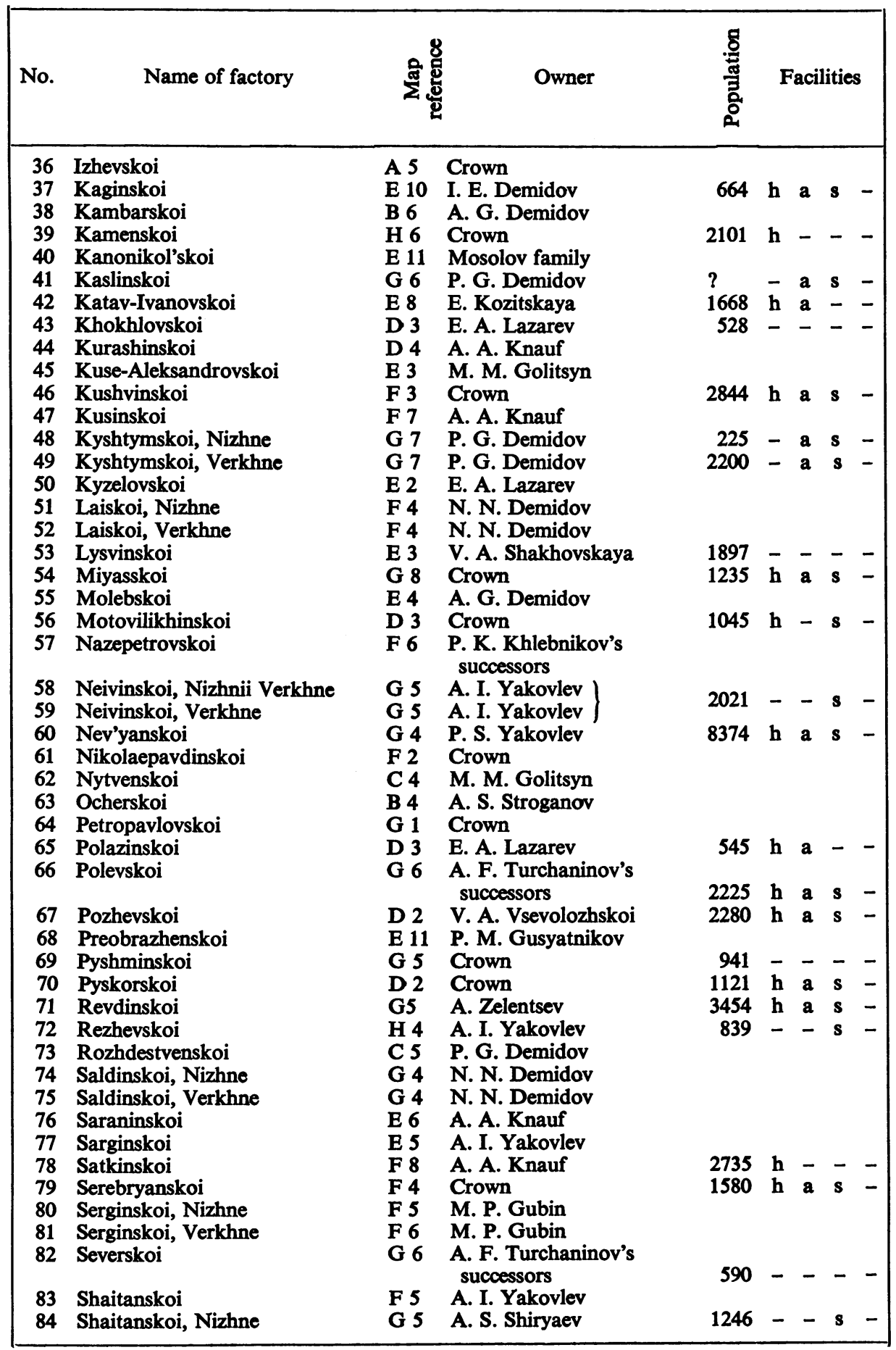


Urals factory hospitals and surgeons

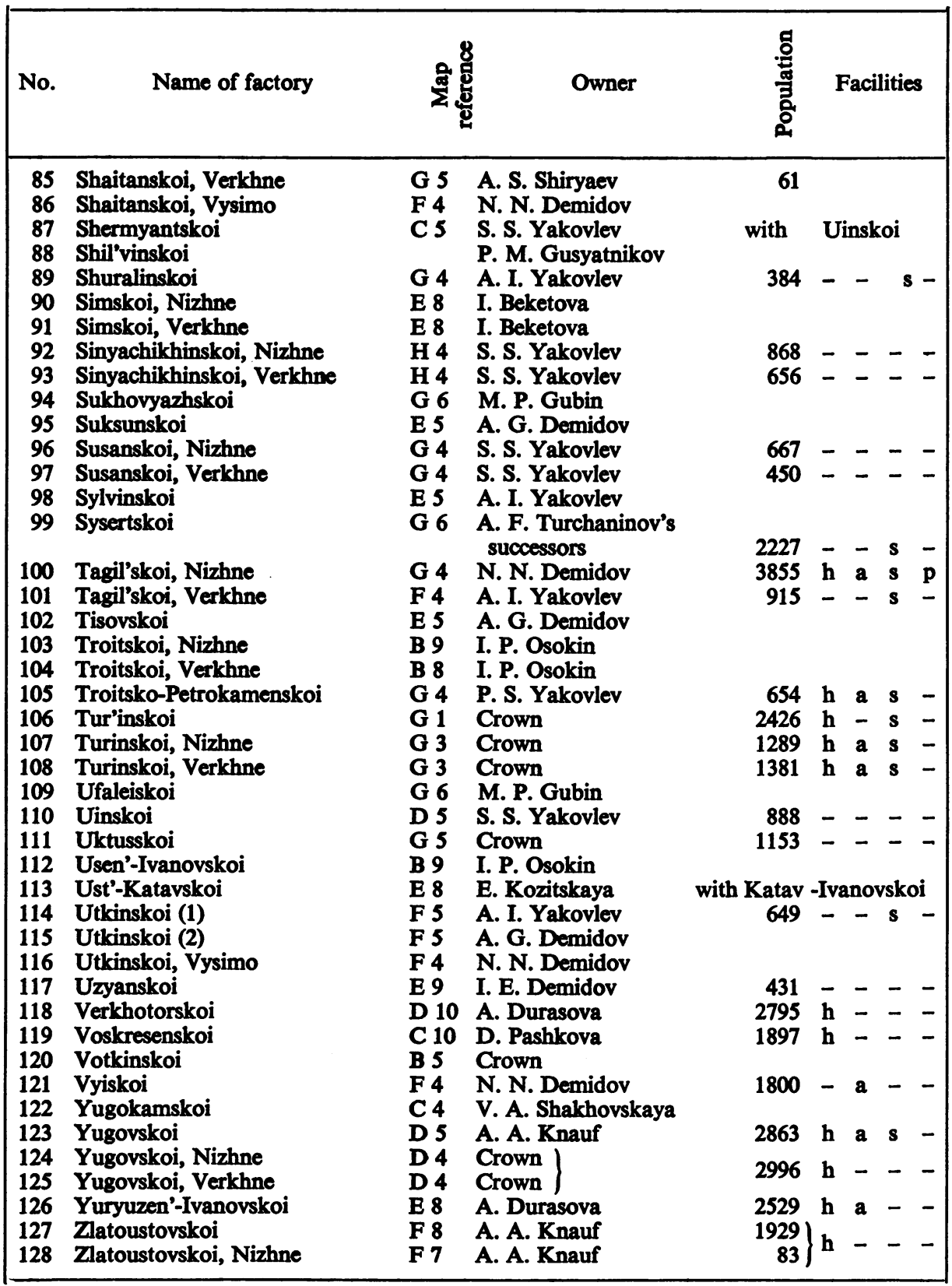

NOTES TO TABLE 1

1. Most factories are named after the river on which they lie: the Alapaevskoi factories, for example, are on the banks of the River Alapaikha. Nizhne, Verkhne, and Vysimo mean Lower, Higher, and Highest respectively.

2. In the "Facilities" columns the letters $h$, a, s, and p indicate the presence of a hospital, assistant or apprentice surgeon, trained surgeon and poorhouse respectively; - implies the absence of the corresponding facility; a blank space signifies that no information is available. 
Basil Haigh

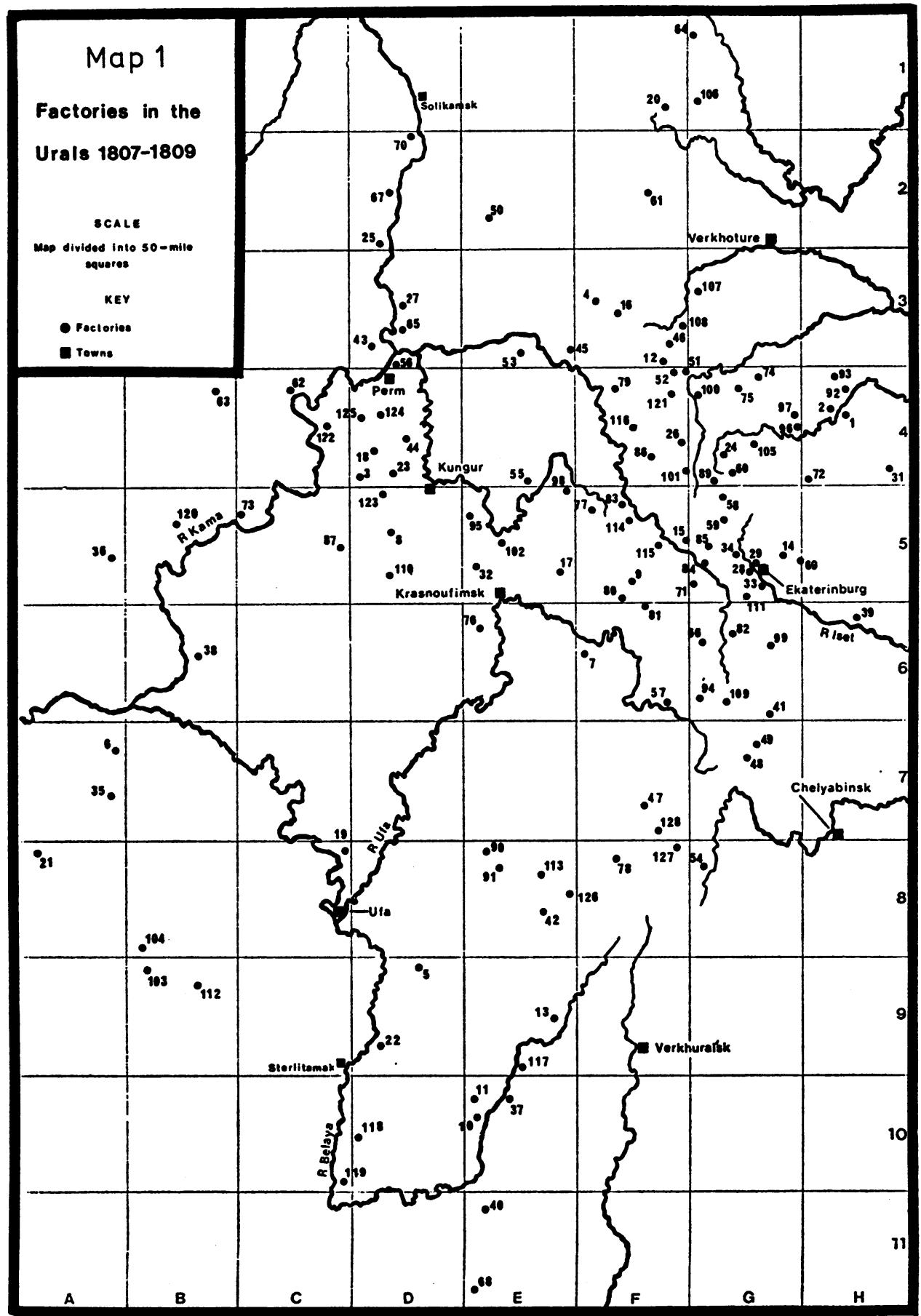




\section{Urals factory hospitals and surgeons}

For information on the medical service provided at the factories the document entitled "Descriptions of the factories of the Urals" can be consulted.32

P. E. Tomilov, Inspector of Mines for the Perm District, was the son of a factory surgeon at the Nerchinsk silver mines in Eastern Siberia. On his appointment as Inspector of Mines in 1807 one of his first duties was to visit as many of the factories as possible, which took him two years. He visited altogether eighty-seven factories, but some of the descriptions have been lost or are incomplete, so that information is available on the medical service at seventy-three factories: eighteen owned by the Crown and fifty-five in private ownership. Among the information which Tomilov gives about the factories he visited are: whether or not a hospital or a poorhouse was provided, a servant or other person was appointed specially to treat the sick, and a surgeon was in residence or on call. The surgeon's name also was given. Tomilov's observations can form the basis of an elementary analysis of the Urals factory medical service.

The first point to note is the virtually complete absence of poorhouses, for one existed only at Nizhne-Tagil'skoi, the largest factory in the Urals (though not the factory with the largest population). Yet plans for the provision of poorhouses at factories have as long a history in Russia as plans for a medical service, and sometimes they were awarded higher priority (by Tatishchev, for instance).

To analyse the information on the medical service it is necessary to devise a valid classification of the seventy-three factories concerned, and several different approaches suggest themselves: ownership, size, and geographical location spring to mind first. None is entirely satisfactory. Because of frequent changes of government policy, the breaking-up of estates on the death of an owner, marriage settlements, and other factors, the distribution of privately owned factories is haphazard, and widely separated factories may belong to the same owner. The largest factory in size and output does not have the largest population, and classification on this basis sometimes gives surprising results. Nevertheless, instructive conclusions can be drawn.

The influence of ownership is most strikingly shown in the case of the Yakovlevs' factories. ${ }^{33}$ After Savva Yakovlev's death in 1784 his factories were eventually divided among his two surviving sons, Sergei Savvich and Petr Savvich, and his grandson Aleksei Ivanovich. Tomilov visited all but three of the twenty-two factories concerned, and the facilities he found are summarized in Table 2.

At Sergei Yakovlev's factories, without exception, there was neither hospital nor surgeon; at Aleksei's factories there was invariably a surgeon or apprentice but never a hospital; at Petr's factories there were both.

22 P. E. Tomilov, Opisaniya zavodov khrebta ural'skago, sostavlennye permskim Berg-Inspektorom P. E. Tomilovym: 1807-09 [Descriptions of the factories of the Ural Range compiled by Perm Inspector of Mines P. E. Tomilov: 1807-09], reprinted in Kozlov, op. cit., note 31 above, pp. 151-298.

a Savva Yakovlevich Yakovlev (1712-1784) was a remarkable man even by Urals standards. Savva Sobakin (sobaka $=$ dog) began life as a humble butcher but, having changed his name in the meantime, at his death he held the rank of College Assessor and left an estate worth seven and a half million roubles, including twenty-two factories. For an account of his entrepreneurial activities, see Pavlenko, op. cit., note 13 above, pp. 248-259. 


\section{Basil Haigh}

TABLE 2

Hospitals and surgeons at the Yakovlevs' factories

\begin{tabular}{|l|c|c|c|c|}
\hline Owner & $\begin{array}{c}\text { Number of } \\
\text { factories } \\
\text { owned }\end{array}$ & $\begin{array}{c}\text { Number } \\
\text { visited } \\
\text { by Tomilov }\end{array}$ & $\begin{array}{c}\text { Number } \\
\text { with } \\
\text { hospital }\end{array}$ & $\begin{array}{c}\text { Number with } \\
\text { surgeon or } \\
\text { apprentice }\end{array}$ \\
\hline Sergei Savvich Yakovlev & 9 & 9 & 0 & 0 \\
Aleksei Ivanovich Yakovlev & 10 & 7 & 0 & 7 \\
Petr Savvich Yakovlev & 3 & 3 & 3 & 3 \\
\hline
\end{tabular}

Although the pattern is not so clear with the other owners, it is possible to generalize. The Knauf factories and those owned by the four daughters of Ivan Semenovich Myasnikov (Irina Beketova, Ekaterina Kozitskaya, Agrafena Durasova, and Dar'ya Pashkova) werevery well provided with hospitals and attendants, whereas the Demidovs' record in this respect varied from bad to appalling.

The effect of factory size could have some influence on this variation in the quality of medical service provided by different owners. Let us examine the distribution of hospitals among factories with different populations: those with less than 1000 , those with 1000 to 2000 , and those with over 2000 persons.

TABLE 3

Hospital provision at Urals factories: all factories

\begin{tabular}{|l|rr|rr|c|}
\hline \multicolumn{1}{|c|}{ Population } & \multicolumn{2}{|c|}{ Hospital } & \multicolumn{2}{c|}{ No Hospital } & Total \\
\hline Over 2000 & 22 & $85 \%$ & 4 & $15 \%$ & 26 \\
1000 to 2000 & 14 & $67 \%$ & 7 & $33 \%$ & 21 \\
Under 1000 & 3 & $11 \%$ & 23 & $89 \%$ & 26 \\
\hline
\end{tabular}

TABLE 4

Hospital provision at Urals factories: Crown factories

\begin{tabular}{|l|cc|cc|c|}
\hline \multicolumn{1}{|c|}{ Population } & \multicolumn{2}{|c|}{ Hospital } & \multicolumn{2}{c|}{ No Hospital } & Total \\
\hline Over 2000 & 8 & $100 \%$ & - & - & 8 \\
1000 to 2000 & 6 & $75 \%$ & 2 & $25 \%$ & 8 \\
Under 1000 & - & - & 2 & $100 \%$ & 2 \\
\hline
\end{tabular}

The facts given in Table 3 are exactly what would be expected: the percentage of large factories with a hospital is much greater than the percentage of small factories with a hospital. The relationship is even more striking for the Crown factories (Table 4). 


\section{Urals factory hospitals and surgeons}

Obviously the size of a factory is a decisive factor determining whether it should be provided with a hospital or not. Let us consider the factories owned by the Yakovlevs again. All the factories owned by Sergei had a population of under 1000, and even at the Crown factories of this size there were no hospitals. If, however, the figures for the private factories are obtained by subtraction, there were three hospitals at fifteen factories with a population of under 1000 in the private sector not belonging to Sergei Yakovlev compared with no hospitals at the nine such factories which he owned. Sergei Yakovlev thus compares very unfavourably with the other private owners.

On the other hand, Aleksei and Petr Yakovlev each owned both large and small factories, but this does not affect the pattern of hospital provision: no hospitals at Aleksei's factories, a hospital at each of Petr's factories.

The situation regarding hospital provision can be summed up as follows: at Crown factories a hospital is always provided if the population exceeds 2000 , never if it is under 1000; at private factories a hospital is usually provided if the population exceeds 2000 , occasionally if it is under 1000-whether a hospital is in fact provided in a particular case depends on the outlook of the owner concerned.

The location of factories at which there was a hospital, with or without staff, is shown for Crown and privately-owned establishments on Map 2 (p. 132).

The information on Urals surgeons given by Tomilov is very incomplete. The chief item of information that is missing is the extent to which the mines and factories could call on the civilian medical services in the region, especially at towns such as Perm, Kungur, Krasnoufimsk, Ufa, Solikamsk, Verkhotur'e, and so on. This period was long before Government attempts to provide a rural medical service based on the Zemstvo system. The medical practitioners in the area were of four categories: (1) army medical officers with military detachments operating there; (2) medical officers, civil and military, appointed to the mines; (3) medical officers attached to the provincial governments; (4) private practitioners.

Tomilov does, however, give the names of surgeons employed at individual factories, and they fall into two clearly defined groups: those serving only one factory, and those serving more than one factory (Map 3, p. 133). ${ }^{34}$

s4 Four surgeons served more than one factory:

(1) Dr. Fel'kner of Ekaterinburg served Nizhne-Tagil'skoi (100, G 4), Kaslinskoi (41, G 6), Verkhneand Nizhne-Kyshtymskoi (49, 48, G 7), Bilimbaevskoi (15, F 5), Polevskoi (66, G 6), Sysertskoi (99, G 6), Verkhne-Isetskoi (34, G 5) and Revdinskoi (71, G 5).

(2) Staff-Surgeon Pashutinskii of Verkhotur'e served Verkhne-Sinyachikhin-skoi (93, H 4), Nizhne-Alapaevskoi (1, H 4), Nev'yanskoi (60, G 4), Byngovskoi (24, G 4) and Troitsko Petrokamenskoi $(105, \mathbf{G} 4)$.

(3) Staff-Surgeon Postupal'skii of Shuralinskoi served Shuralinskoi (89, G 4), Utkinskoi (114, F 5), Verkhne-Tagil'skoi (101, F 4), Verkhne-Neivinskoi (59, G 5), Nizhnii Verkhne-Neivinskoi (58, G 5) and Rezhevskoi (72, $\mathrm{H} 4$ ),

(4) Chief Surgeon Arkhangel'skii of Kushvinskoi served Kushvinskoi (46, F 3), Serebryanskoi (79, F 4), Baranchinskoi (12, F 3), Verkhne- and Nizhne-Turinskoi (108, 107 G 3) and NizhneTagil'skoi (100, G 4).

Thirteen surgeons served one factory each: Surgeon Varvinskii: Nizhne-Shaitanskoi (84, G 5), Staff-Surgeon Rovnev: Pozhevskoi (67, D 2), Dr. Bergman: Chermoskoi (25, D 2), Staff-Surgeon Grobnitskii: Bogoslovskoi (20, F 1), Surgeon Balanovskii: Turinskoi Mine (106, G 1), Staff-Surgeon 


\section{Basil Haigh}

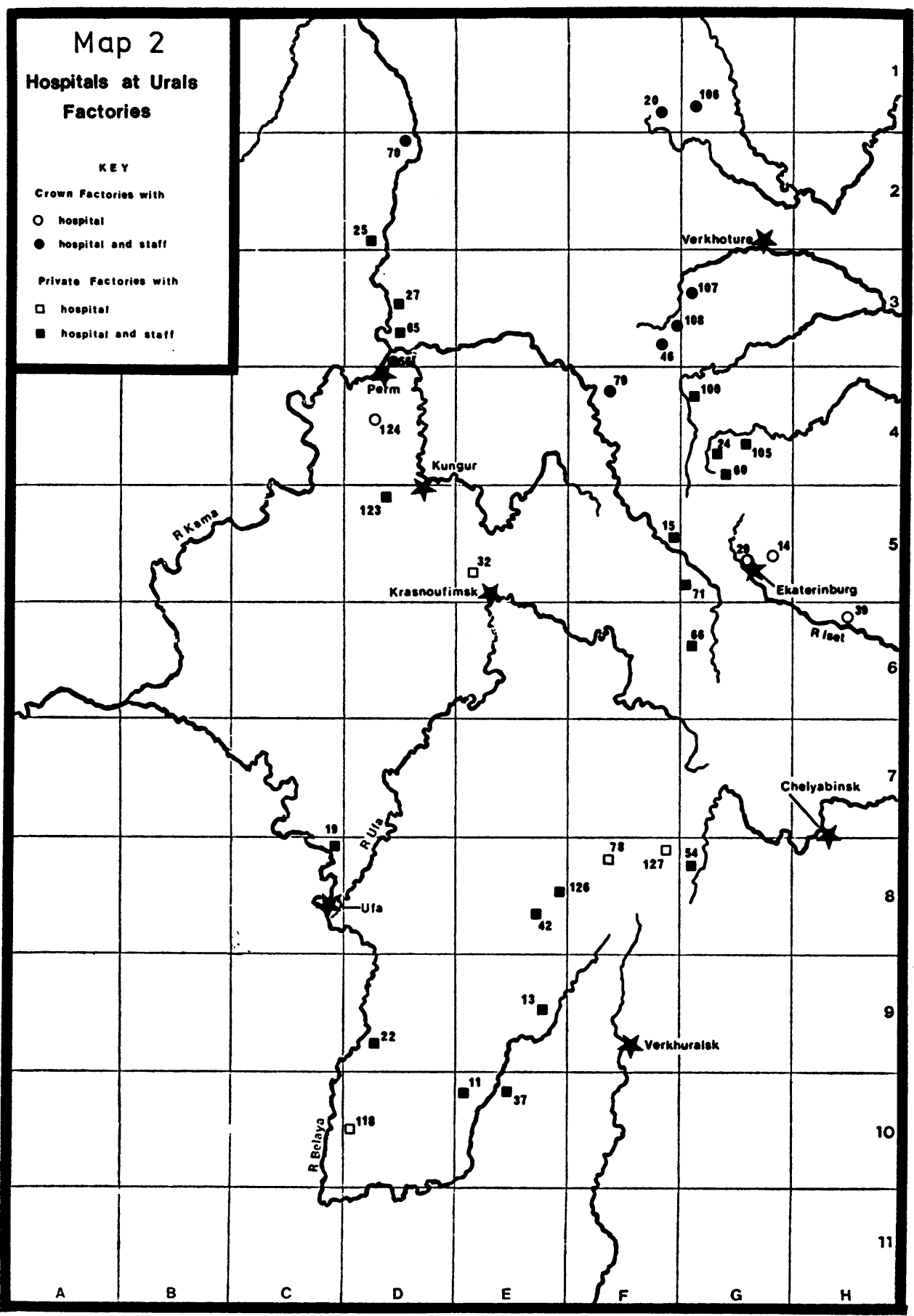


Urals factory hospitals and surgeons

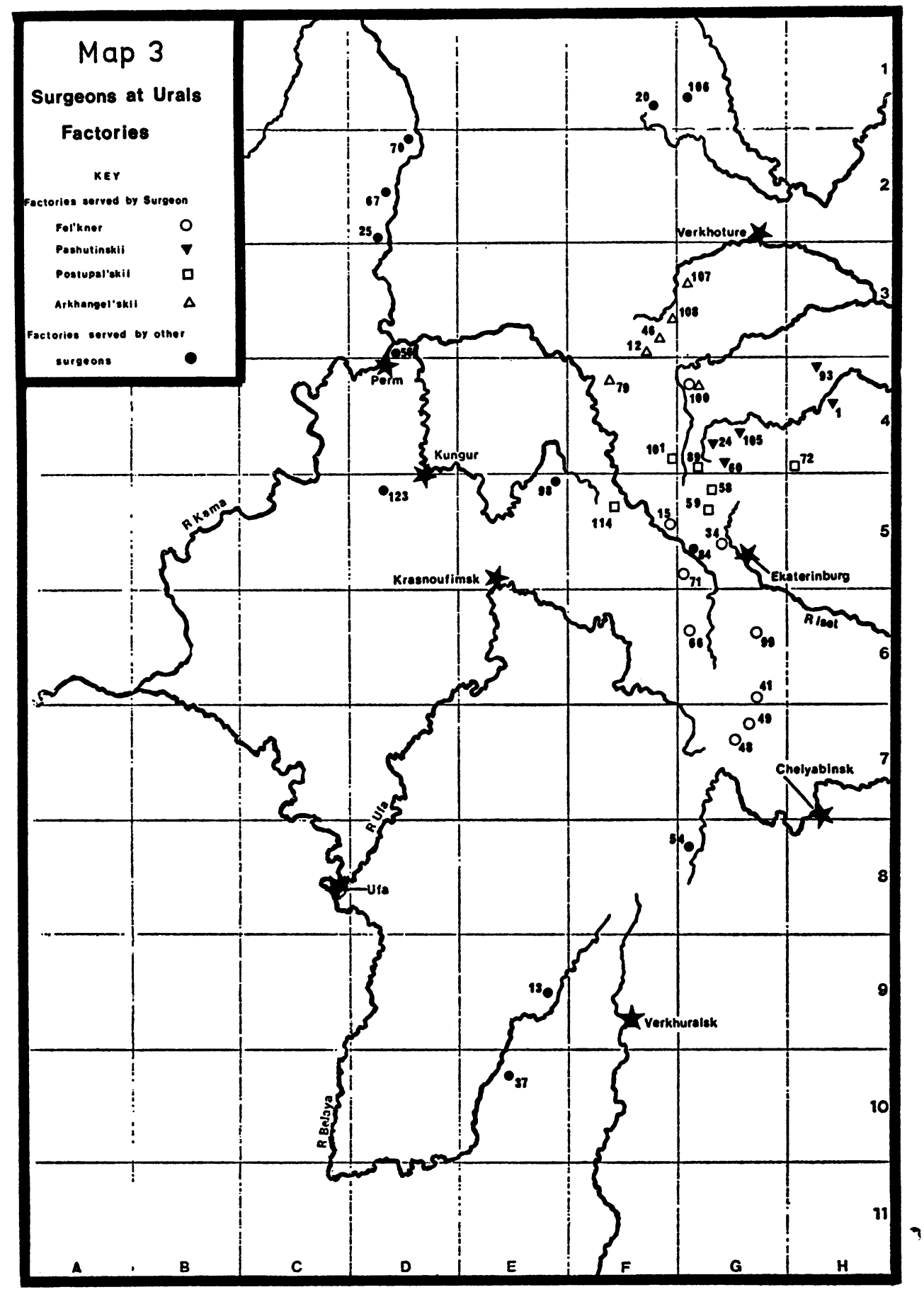




\section{Basil Haigh}

The distinction is very sharp: in the first group one surgeon serves at least six factories, whereas in the second there is a surgeon, or even a surgeon and his assistant to each factory. It suggests that some fundamental cause is responsible for the two categories of surgeon-factory relationship.

Examination of Map 3 gives a possible clue. All four surgeons serving several (more than six) factories worked on the Siberian side of the Ural Mountains whereas all surgeons working on the western (European) side of the Urals served a single factory.

The explanation could be that on the more settled European side of the Urals, with a larger population and a more diversified employment and with more numerous centres of population, surgeons and physicians who were working in that region already in civil or military practice or in the service of the provincial government were hired by the owners of a large factory. On the Siberian side of the Urals, where conditions were less settled and mining was the chief activity of the population, and where the only town of any significance, Ekaterinburg, was itself the centre of the mining and metallurgical industry, it was rare for a suitable surgeon to reside near a factory. Accordingly, the solution was adopted of appointing one surgeon to a group of factories.

The distribution of the factories by size and by the availability of a surgeon or apprentice is shown in Table 5, for the sixty-eight factories for which the information is reliable. Of the twenty-five largest factories sixteen (64 per cent) had the services of a surgeon, but seven ( 28 per cent) had no treatment staff. Three of the latter were Crown factories on the outskirts of Ekaterinburg, however, and they could make use of the town's hospital facilities, so that the omission was not as serious as it might appear at first sight. Of the twenty-four smallest factories seven (29 per cent) had the services of a surgeon but sixteen (67 per cent) had no treatment staff. This is the expected pattern. What is perhaps surprising is the provision of a surgeon at seven of the smallest factories and, less satisfactory, the absence of treatment staff at seven of the largest factories.

The figures for private factories follow the general pattern closely, but only 40 per cent of these factories (twenty-one of fifty-three) had the services of a surgeon compared with 44 per cent of all factories (thirty of sixty-eight) and with 60 per cent (nine of fifteen) of the Crown factories.

The figures for the Crown factories are perhaps the most interesting. If the factories visited by Tomilov are typical of the group as a whole the following conclusions can be drawn: (1) the policy at Crown factories was not to appoint unsupervised apprentices at all; (2) neither surgeons nor apprentices were appointed to the factories of the smallest group, with a population of under 1000; (3) at the larger factories, with a population greater than 1000 , it was the rule to appoint a qualified surgeon; in fact, if the three Crown factories on the outskirts of Ekaterinburg are accepted as

Protasov: Motovilikhinskoi (56, D 3), Assistant Surgeon Cherepenin: Pyskorskoi (70, D 2), Surgeon Shpakovskii: Pyskorskoi (70, D 2), Staff-Surgeon Romanovskii: Miyasskoi (54, G 8), Staff-Surgeon Romanovskii (a different person, evidently): Yugovskoi (123, D 5), Surgeon Orlovskii: Kaginskoi (37, E 10), Staff-Surgeon Kuryshev: Beloretskoi (13, E 9), and Staff-Surgeon Barulin: Sylvinskoi (98, E 5). 


\section{Urals factory hospitals and surgeons}

possessing a hospital and staff, 80 per cent of the larger Crown factories (twelve of fifteen) had a surgeon and 60 per cent (nine of fifteen) had a trained apprentice or apprentices as well. This suggests that, as with hospitals, the staffing arrangements also were rather better at the Crown than at private factories.

TABLE 5

Provision of surgeons and apprentices at Urals factories

\begin{tabular}{|c|c|c|c|c|c|c|c|c|}
\hline Population & \multicolumn{2}{|c|}{$\begin{array}{l}\text { Surgeon and } \\
\text { apprentice }\end{array}$} & \multicolumn{2}{|c|}{$\begin{array}{l}\text { Surgeon } \\
\text { only }\end{array}$} & \multicolumn{2}{|c|}{$\begin{array}{l}\text { Apprentice } \\
\text { only }\end{array}$} & \multicolumn{2}{|c|}{ No staff } \\
\hline $\begin{array}{l}\text { All factories (68) } \\
\text { Over } 2000\end{array}$ & 11 & $16 \%$ & 5 & $7 \%$ & 2 & $3 \%$ & 7 & $10 \%$ \\
\hline 1000 to 2000 & 6 & $9 \%$ & 1 & $1 \%$ & 5 & $7 \%$ & 7 & $10 \%$ \\
\hline Under 1000 & 3 & $4 \%$ & 4 & $6 \%$ & 1 & $1 \%$ & 16 & $24 \%$ \\
\hline $\begin{array}{l}\text { Private factories (53) } \\
\text { Over } 2000\end{array}$ & 10 & $19 \%$ & 3 & $6 \%$ & 2 & $4 \%$ & 4 & $8 \%$ \\
\hline 1000 to 2000 & 1 & $2 \%$ & 0 & 0 & 5 & $9 \%$ & 6 & $11 \%$ \\
\hline Under 1000 & 3 & $6 \%$ & 4 & $8 \%$ & 1 & $2 \%$ & 14 & $26 \%$ \\
\hline $\begin{array}{l}\text { Crown factories (15) } \\
\text { Over } 2000\end{array}$ & 1 & $7 \%$ & 2 & $13 \%$ & 0 & 0 & 3 & $20 \%$ \\
\hline 1000 to 2000 & 5 & $33 \%$ & 1 & $7 \%$ & $\mathbf{0}$ & 0 & 1 & $7 \%$ \\
\hline Under 1000 & 0 & 0 & $\mathbf{0}$ & $\mathbf{0}$ & $\mathbf{0}$ & 0 & 2 & $13 \%$ \\
\hline
\end{tabular}

It remains to attempt to compare very briefly the state of industrial medicine in the mining and metallurgical industry as it existed in Russia and Great Britain at the beginning of the nineteenth century. Clearly the contrasts far outweigh the similarities, for the conditions of the industry in the two countries were widely different. In Russia, despite the often thriving private sector, part of the industry was always under Crown ownership and the rest under close Government supervision and control. In Great Britain it was entirely under private ownership. The factories themselves in Russia were usually larger, for reasons already discussed. With a few exceptions, the Urals factories were remote from towns and dependent on themselves or on other factories for services.

Consequently, in Russia both the need for local provision of medical services at factories and the machinery of centralized (State) organization of such services were far stronger than in Great Britain. The fact that the Russian factories were under close government control also meant that their activities are well documented in accessible official records, whereas in Great Britain the relevant information is generally concealed in scattered archives or is non-existent.

The classical authorities on the history of the iron and steel industry in Great 


\section{Basil Haigh}

Britain $^{35,36}$ do not mention medical problems. Of those histories of individual firms that do discuss such matters, the evidence is mainly scanty. The Carron Company in Falkirk ${ }^{37}$ "had little sympathy with workmen in illness, not even with those suffering from accidents at work." No factory hospital existed, but the local doctor could be called in by the company at its expense. A more interesting example is the London (Quaker) Lead Company, ${ }^{38}$ formed in 1704, which first organized a medical service for its mines on Alston Moor in Cumberland in about 1800, subscribed towards the maintenance of a medical officer at the mines in 1813, and appointed its own surgeons and assistants as company officers in 1827. Perhaps the most illuminating example of all is the Crowley Ironworks in County Durham, whose "Law Book"39 records how John Crowley "... . in the year 1724 taking into my consideration the deplorable state of my honest and laborious workmen and their families ...", appointed an "able surgeon and one who is also well skilled in physick with all proper medicines and druggs at my own proper cost and charge to constantly attend upon them in such indispositions."

The parallel with Hennin and Tatishchev here is very close, and it is also worth recalling that $\mathbf{1 7 2 4}$ was the year that saw the first surgeon appointed to a Russian factory by Royal ukase.

In the Cornish tin mines a system of "bal" (mine) surgeons was begun early in the eighteenth century, and for the surgeon's services the men paid $2 d$. per month from their wages. ${ }^{40}$ The patients were treated in their own homes, at least until the first hospital was built in the county, in Truro in 1799. Despite the small area of the tin mining district and the relative proximity of the mines, the system proved inconvenient for both patients and surgeon. ${ }^{41}$ Yet the problems were infinitesimal compared with those in the Urals, where distances were enormous and communications atrocious for a good part of the year.

The nearest parallel in England to the Urals factories, so far as the provision of a medical service is concerned, is the Royal dockyards, where the population at risk was comparable. Surgeons were appointed to the dockyards as early as the seventeenth century, ${ }^{42}$ but since the dockyards were in towns, hospitals were not specially built for them.

${ }^{25}$ H. R. Schubert, History of the British iron and steel industry, c. 450 B.C.-A.D. 1775, London, Routledge \& Kegan Paul, 1957.

${ }^{36}$ E. Straker, Wealden iron, London, G. Bell, 1931.

${ }^{87}$ R. H. Campbell, Carron Company, Edinburgh and London, Oliver \& Boyd, 1961, p. 67.

${ }^{28}$ A. Raistrick, Two centuries of industrial welfare: the London (Quaker) Lead Company, 1692-1905

London, Friends' Historical Society, 1938, pp. 48-49. (Revised edition, Buxton, Moorland, 1977.)

s2 The Law Book of the Crowley Ironworks, edited and with an introduction by M. W. Flinn, Publications of the Surtees Society, vol. CLXVII, Durham, 1952.

${ }^{10}$ A. K. Hamilton-Jenkin, The Cornish miner, 2nd ed., London, Allen \& Unwin, 1948, p. 141.

41 "The bal surgeons begin to be weary of such a practice where an accident of consequence may require at least six weeks' daily attendance five or six miles from his residence, whilst another of like nature may require the same attendance five or six miles diametrically opposite." (William Pryce, Mineralogia Cornubiensis, London, J. Phillips, 1778, p. 177.)

12 Dockyard surgeons were first appointed in 1625 at Chatham, and in 1698 seven yards each had one surgeon. No definitive history of the dockyard medical services, to the writer's knowledge, has yet been published. See J. J. Keevil, Medicine and the Navy, vol. 1 (1200-1649), Edinburgh and London, Livingstone, 1957, p. 205; The Sergison papers, collected and edited by R. D. Merriman, Greenwich, Publications of the Navy Records Society, vol. 89, 1950, p. 344. 


\section{Urals factory hospitals and surgeons}

But these are isolated examples and probably exceptional. Until a statistical survey can be made of the British metallurgical industry at the beginning of the nineteenth century, only the most general comparison can be made with the situation in Russia.

Because of the military character of the organization of Russian industry, the prevalence of inefficient serf labour and the consequent large population at the factories, most of which were in remote parts of the country, it is more common to find factories equipped with a medical service in Russia at this time than in Great Britain. The much greater involvement of the State in industrial affairs in Russia than in Great Britain had the result that legislation on the health and welfare of the factory worker began to appear much earlier in Russia and on the whole it is much more comprehensive in scope, more embracing in detail and more enlightened in outlook than in Great Britain. The existence of legislation, however, by no means implies its enforcement.

\section{SUMMARY}

The results of a survey of the medical facilities provided at the mines and metallurgical factories in the Ural Mountains in 1807-1809 are described and analysed in relation to size and ownership of the factories. As is to be expected, facilities were better at larger factories as a rule, and the Crown provided better facilities than, on average, the private owners. Striking differences are revealed in the standards of medical care provided by different private owners. The pattern of appointment of surgeons to the factories differed on the two sides of the Urals and a possible reason is suggested.

The history of previous legislation in Russia on industrial health and welfare, starting from the Admiralty Regulations in 1722 and ending with the Mining Regulations of 1806 , is briefly reviewed. 